Jean-Pierre Tranchant*

\title{
Is Regional Autonomy a Solution to Ethnic Conflict? Some Lessons from a Dynamic Analysis
}

DOI 10.1515/peps-2016-0028

Previously published online November 22, 2016

Abstract: Does granting regional autonomy to concentrated minorities appease their demand for sovereignty or instead motivate and enable them to engage in secessionist conflicts? To answer this question is difficult as moves towards federalism and decentralization are themselves the results of strategic interactions between the state and the minorities. In this note, I intend to shed some light on this question by looking at how ethnic civil wars and autonomy are dynamically linked. This shows that for locally dominant groups, the risk of war monotonically decreases in the years leading to and following autonomy. For groups that are a minority locally, however, the risk of war sharply increases in the lead-up to autonomy, and quickly falls afterwards, suggesting strategic behavior.

Keywords: decentralization, regional autonomy, civil wars, ethnic conflict

\section{Introduction}

In his book “Containing Nationalism”, Hechter $(2000,139)$ distinguishes federations from other forms of political devolution by making the case that "regional autonomy and representation [the key features of federations, Nda] are constitutionally guaranteed." ${ }^{1}$ The appeal of such territorial power-sharing arrangements is strong: it is based on the prospect of preserving the territorial integrity of the state while allowing concentrated minorities a sufficient degree of self-rule within their region to discourage them to take up arms (e.g. Lustick, Miodownik, and Eidelson 2004; Nordquist 1998; Riker 1964). ${ }^{2}$ Specifically, regional autonomy

1 For a wider discussion on how federations hold together and the political aspects of fiscal federalism and decentralisation, see Weingast (2014).

2 This view is reminiscent of the discussion on the merits of consociationalism in Lijphart (1969, 219) according to which "sub-cultures with widely divergent outlooks and interests may coexist without necessarily being in conflict" if they are separated by clear boundaries.

*Corresponding author: Jean-Pierre Tranchant, Institute of Development Studies, University of Sussex, Library Road, Brighton, BN1 9RE, United Kingdom of Great Britain and Northern Ireland, E-mail: jp.tranchant@ids.ac.uk 
is supposed to curb violent secessionism by enabling minority members to implement policies closer to their preferences; hence increasing their welfare. ${ }^{3}$ Regional autonomy is indeed a frequent institutional response to ethnic conflict. According to the Ethno-Power Relations (EPR) dataset (Vogt et al. 2015), about $25 \%$ of groups over the period 1950-2010 enjoy some form of regional autonomy at any time. The relative successes of Switzerland, Canada and Belgium have given credence to this thesis (Bachtinger and Steiner 2004; Hooghe 2004; Lijphart 1996). But other prominent scholars have taken the opposing stance: in their view, regional autonomy fosters separatist tendencies by giving minorities financial and institutional resources to fight (Cornell 2002; Hale 2004; Roeder 1991) and by giving legitimacy to national demands and identities (Hardgrave 1993; Kymlicka 1998). The fragmentation and collapse of the Soviet Union and Yugoslavia (Bunce 1999; Cornell 2002; Roeder 1991) and ongoing conflicts in federations (see e.g. Suberu 2001, on Nigeria) support this case.

Econometric studies based on cross-country (or cross-ethnic groups) analyses lean towards the first view. Exploiting the EPR dataset, Cederman et al. (2015) have found that ethnic groups which enjoy some form of territorial power-sharing with the center are less likely to participate in civil wars than others. Tranchant (2016) combines the EPR dataset with information on the autonomy of regional governments (from the Regional Autonomy Index dataset) and estimates by dynamic panel methods the effect of various facets of decentralisation and autonomy on the incidence of ethnic civil wars between 1950 and 2010. He found that ethnic groups whose regional governments enjoy a formal autonomy status and wide representation powers are less likely to be involved in civil wars. ${ }^{4}$ Both studies use an instrumental variable approach to account for the fact that groups which are, ceteris paribus, more likely to be violent are also more likely to be granted autonomy. Christin and Hug (2012) find that ethnofederations are less likely to experience civil wars than unitary countries, but that the effect is reversed when too large a share of territorial subunits become autonomous. ${ }^{5}$

This evidence suggests that the conflict-mitigating impact of autonomy trumps the reverse effect, i.e. that groups strategically engage in fighting to

3 In heterogeneous countries, central policies are unlikely to match the preferences of minorities, either because they are uniform or because of a "spatial decay" in their implementation in far-flung territories that reduce the quantity of public good actually provided (Panizza, 1999).

4 The effect is maximal when formal autonomy is combined with actual powers of of policy and representation.

5 Murshed, Tadjoeddin, and Chowdhury (2009) find a similar conflict-mitigating effect of fiscal decentralisation through an econometric analysis set-up within a single country, i.e. Indonesia. 
obtain autonomy. Yet, much remains to be known to make most sense of these results. When is regional autonomy most likely to be granted? Is it in the midst of protracted conflict? When conflicts start? Or before violence takes place? What is the conflict behavior of groups in the run-up to and following the obtaining of autonomy? Finally, is there any evidence that autonomy generates negative spillovers by encouraging other groups to fight? In this note, I aim to clarify the debate around regional autonomy and conflict by providing some answers to these questions with the help of the Ethno-Power relations (EPR) and Regional Autonomy Index (RAI) databases and my own work on classifying groups as local majorities and local minorities.

\section{Timing of regional autonomy}

I use two sources of information on regional autonomy. The first one is the EthnoPower Relations dataset (EPR) which documents access to power and participation in civil wars (among other things) for all politically relevant groups in the world between 1946 and 2013. It includes a variable of regional autonomy, defined as substantial territorial power-sharing between the center and the region in which the minority lives. The second one is the regional autonomy index (RAI) which measures the extent of autonomy, self-rule and shared-rule of up to 5 tiers of regional governments in 81 countries between 1950 and 2010. The definition of regional autonomy slightly differs between the two datasets. The EPR uses the notion of territorial power-sharing to define autonomy whereas RAI merely looks at the existence of a special relationship between the center and the region, in the form of a bilateral treaty, that sets it apart from other regional governments. The RAI's definition tells nothing of the actual powers of the autonomous regional government, hence it will be referred to thereafter as "formal autonomy". The EPR's definition is based on actual devolution of powers and will be referred to as “actual autonomy". For countries present in both EPR and RAI datasets, I have matched the information on autonomy and decentralisation of regional governments contained in RAI to all ethnic groups living in these boundaries (and present in EPR). ${ }^{6}$ The RAI definition is more restrictive as only $10 \%$ of groups experienced formal autonomy at any time over the period 1950-2010.

6 This was only done for spatially concentrated minorities. Further details are provided in Tranchant (2016).

7 The corresponding figure for actual autonomy is 30\% on the subsample of 81 countries covered by RAI. 
From the viewpoint of states, granting regional autonomy is not desirable. It consists of giving up parts of their sovereignty and it may be a path towards secession (e.g. Cornell 2002; Toft 2003). Furthermore, granting autonomy to a group may set a precedent and encourage others to demand it (Walter 2006; Forsberg 2013). It follows then that we can expect states to grant regional autonomy as a last resort, either to put an end to a conflict or to prevent a territorial conflict to become (more) violent.

The data seem to corroborate such a view. According to EPR, there have been 262 instances of groups being granted autonomy between 1950 and 2010 . In almost $10 \%$ of these cases, the group concerned was currently involved in an ethnic civil war. As a comparison, the proportion of groups taking part in civil wars in years where autonomy was not given is $3 \%$. Similarly, $11.4 \%$ of groups were in conflict when they were granted formal autonomy while just $1.9 \%$ were in conflict during years when autonomy was not given. Formal and actual autonomies seems then to be particularly likely to happen during a conflict. And when it is so, the conflict in question has usually been going on for a while. The average duration of ongoing civil wars at the moment autonomy is given is 6.8 years, ${ }^{8}$ which suggests that states do use the autonomy card when faced with protracted ongoing conflicts that they cannot stop otherwise.

Autonomy is also likely to be given after conflict has repeatedly taken place. Calculations based on EPR and RAI data show that the chances of obtaining formal autonomy are more than thrice as large (30\% against $8 \%$ ) for groups with three occurrences of past conflict than for groups with no history of conflict. The same also applies for actual autonomy: groups with three past conflicts have more than $50 \%$ of chance of experiencing autonomy against less than $20 \%$ chance for groups with no past conflict.

\section{Dynamics of regional autonomy and civil war}

We have seen that formal autonomy - and to a lower extent territorial powersharing - are likely to be granted during a protracted conflict. This is consistent with two sharply opposing theories on the role of autonomy. On the one hand, some researchers argue that it is the threat or the cost of ethnic rebellion that push central governments to credibly decentralize (through e.g. autonomy) to both preserve the union and reduce violence (see e.g. Nordquist 1998; Hechter

8 The median duration of civil wars is 4 and the average is 7.6 years. 
2000; Panizza 1999). On the other hand, as discussed earlier, other scholars argue that the prospect of obtaining an autonomy status may be to conduce groups to engage in ethnic warfare (Cornell 2002; Walter 2006). According to this interpretation, autonomy is not the solution to ethnic conflict but instead its cause. These views generate different predictions as to how the profile of violence should look like in the run up to and after autonomy is granted. If autonomy is used by central governments to find a durable solution to ethnic violence, then one would expect that the risk of civil wars to start decreasing once autonomy becomes anticipated and even more so when negotiations formally start. If autonomy is successful at mitigating conflict, then the risk of civil wars will sharply reduce after autonomy is obtained. If, on the contrary, autonomy fuels conflict through legitimizing and strengthening separatists, then the risk of civil wars should remain high or even increase in the years following the policy change. Finally, if ethnic wars are strategically engineered to obtain autonomy, then risks of civil wars may actually increase in the years leading up to the granting of autonomy status but sharply diminish thereafter. ${ }^{9}$

I combined data from EPR and RAI to estimate non-parametrically the risk of civil war before and after autonomy was first given for each group which were ever autonomous at some point between 1950 and 2010. The non-linear relation between the risk of civil war and years before and after autonomy is calculated by using the Baltagi and Li's (2002) series semiparametric fixed-effects regression estimator on the sample of geographically concentrated and politically excluded groups..$^{10}$ Figure 1 plots the dynamics of civil war risks against the timing of autonomy. It shows that ethnic groups become more likely to participate in civil wars in the years prior to obtaining formal autonomy status. The risk of a given group to participate in a civil war goes from $1.9 \% 10$ years before autonomy to a peak of $3.4 \% 4$ years before autonomy. The risk of civil war then monotonically decreases until it becomes virtually null 10 years after autonomy.

Three main insights are gained from the plot. First, such a dynamic profile of civil wars contradicts the view that autonomy further fuels conflict. In fact the risk of civil wars strongly decreases after autonomy is granted. Second, the reduction in the chances of war in the immediate years preceding autonomy suggests that incentives for conflict abates once groups anticipate that an institutional solution will be implemented. Third, the increasing risk of war on the period between 10

9 Note that it is also possible that conflict intensifies just before autonomy is granted as groups try to improve their bargaining positions even if they did not start a war to obtain autonomy in the first place.

10 Adding the time-varying control variables used in Tranchant (2016) does not significantly change the estimates. The estimations have been run with the xtsemipar command in stata. 


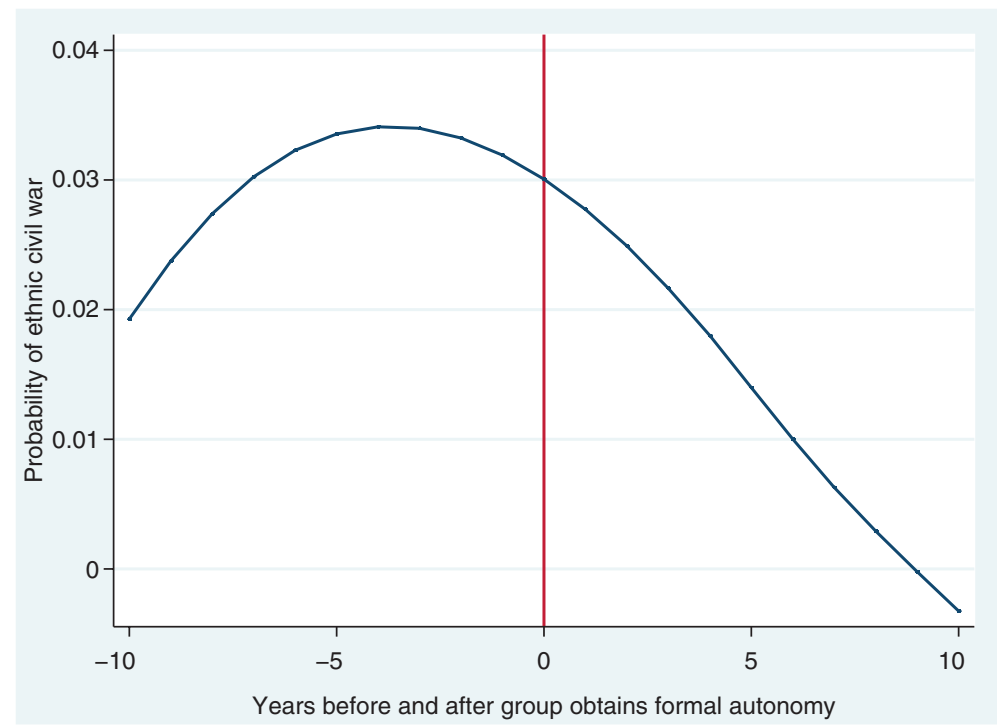

Figure 1: Risk of ethnic civil wars in the years leading up to and following formal regional autonomy.

Source: Author' calculations based on EPR and RAI data. Formal autonomy stems from the RAI dataset. The risk of civil war is estimated by semiparametric groups fixed-effects regression.

and 4 years prior to autonomy is consistent with a strategic use of war to obtain autonomy.

To go further in the analysis, I present separate plots for local minorities and local majorities. Following Tranchant (2016), I consider ethnic groups that are demographically dominant within the boundaries of at least one regional government to be local majorities. ${ }^{11}$ While such local majorities represent $50 \%$ of all the groups in the sample, they represent $80 \%$ of all the groups in conflict. Local majorities are more likely to be involved in civil wars as both the feasibility and legitimacy of secessionist demands are stronger for locally dominant groups than for groups which are a minority even within the region they are concentrated in (Fearon and Laitin 1999; Toft 2003; Tranchant 2008).

We can see in Figure 2 that the risk of civil wars for local majorities increases as we approach autonomy (from $4.1 \% 9$ years prior to autonomy to $5.6 \% 4$ years

11 For instance, the "Indigenous People of the Andes" of Peru are a local majority: they represent a majority in some departments or regions, whereas "Afroperuvians" are not. Even if they are regionally concentrated within Peru, they do not constitute the local majority in a single department or region. 


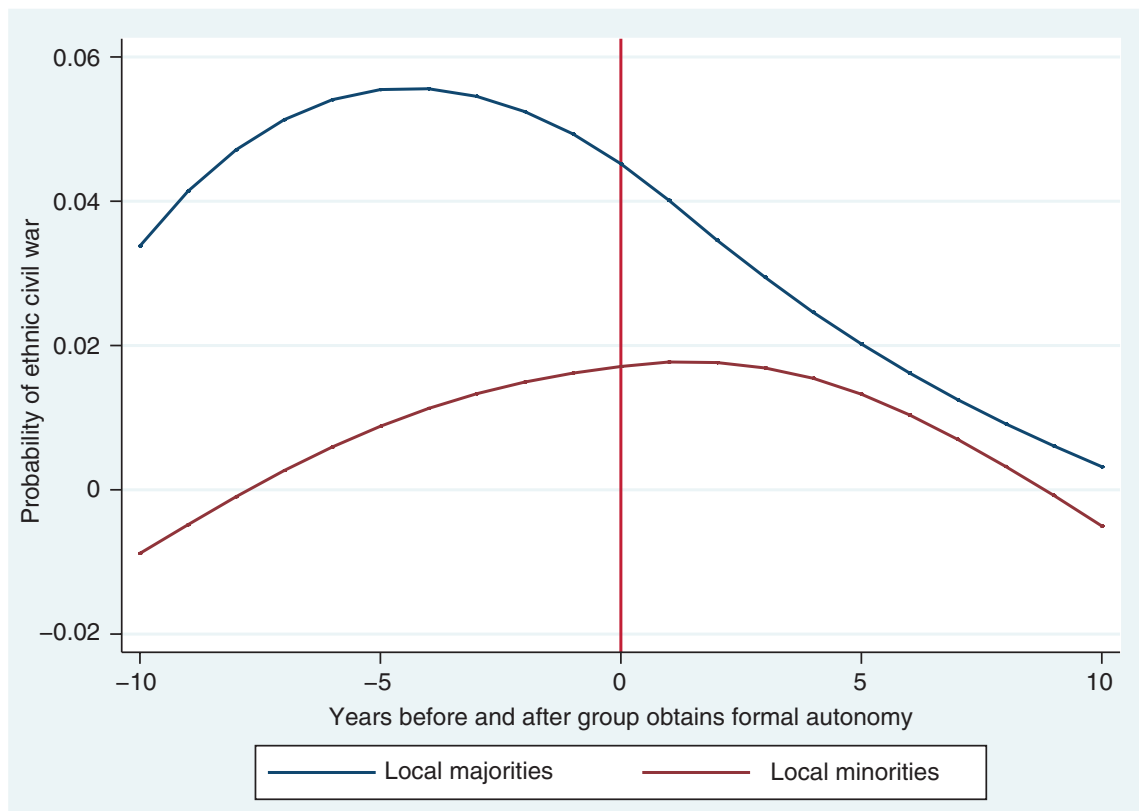

Figure 2: Risk of ethnic civil wars in the years leading up to and following formal regional autonomy - local majorities and local minorities.

Source: Author' calculations based on EPR and RAI data. Formal autonomy stems from the RAI dataset. The risk of civil war is estimated by semiparametric groups fixed-effects regression.

before), and then monotonically decreases until it becomes null 10 years after autonomy. The much lower risk of civil wars 10 years after autonomy than 10 years before is very consistent with the view that autonomy successfully contains ethnic violence. The increase in the risk of civil war in the years leading up to autonomy can be interpreted either as a strategic use of violence to obtain autonomy from local majorities or as a sign that concentrated minorities pose a large secession threat in the absence of robust decentralisation and autonomy arrangements. The dynamic analysis alone cannot discriminate between the two interpretations but the econometric results of Cederman et al. (2015) and Tranchant (2016) suggest a conflict-mitigating role of autonomy and give credence to the latter.

The risk of civil wars for local minorities strongly increases in the years prior to autonomy (from being virtually non-existent 10 years before autonomy to $1.7 \%$ at the time autonomy is granted and in the two following years). It then quickly diminishes and falls to $0 \% 8$ years after autonomy. Such a pattern of quickly rising and ebbing violence around the time of autonomy is well illustrated by the 
case of the Sumus in Nicaragua. According to EPR, the Sumus were involved in an ethnic civil war for the first time in 1982. The war continued for 4 years until, in 1987, the Sumus obtained a formal autonomy status. The conflict then lingered for 3 more years before it eventually ended in 1991. The fact that conflict for local minorities is so much more likely in the years immediately preceding formal autonomy than it is 10 years before or after autonomy is strongly suggestive that conflict may be waged by local minorities to obtain autonomy in the first place. A potential explanation is that the relative lack of legitimacy of secessionist claims by local minorities make them unlikely to obtain large degree of self-rule unless they engage in violence.

Figure 3 provides the same analysis with actual autonomy (i.e. territorial power-sharing) instead of formal autonomy. I cannot distinguish between local majorities and local minorities for all groups in the EPR dataset but the dynamics of risk of civil wars for all groups is strongly indicative that autonomy helps abate conflict. The risk of civil war monotonically decreases in the period leading up to autonomy (going from 3.8\% 10 years before autonomy to $2 \%$ at the time of

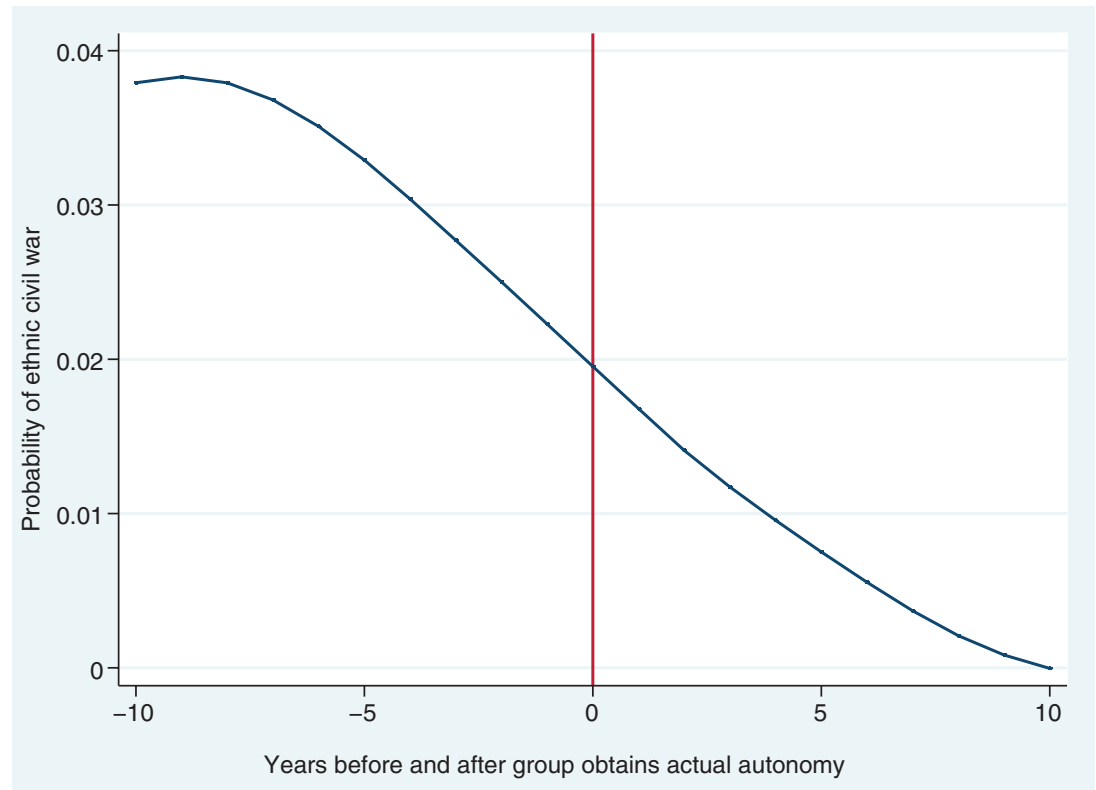

Figure 3: Risk of ethnic civil wars in the years leading up to and following actual regional autonomy.

Source: Author' calculations based on EPR data. Actual autonomy stems from the EPR dataset. The risk of civil war is estimated by semiparametric groups fixed-effects regression. 


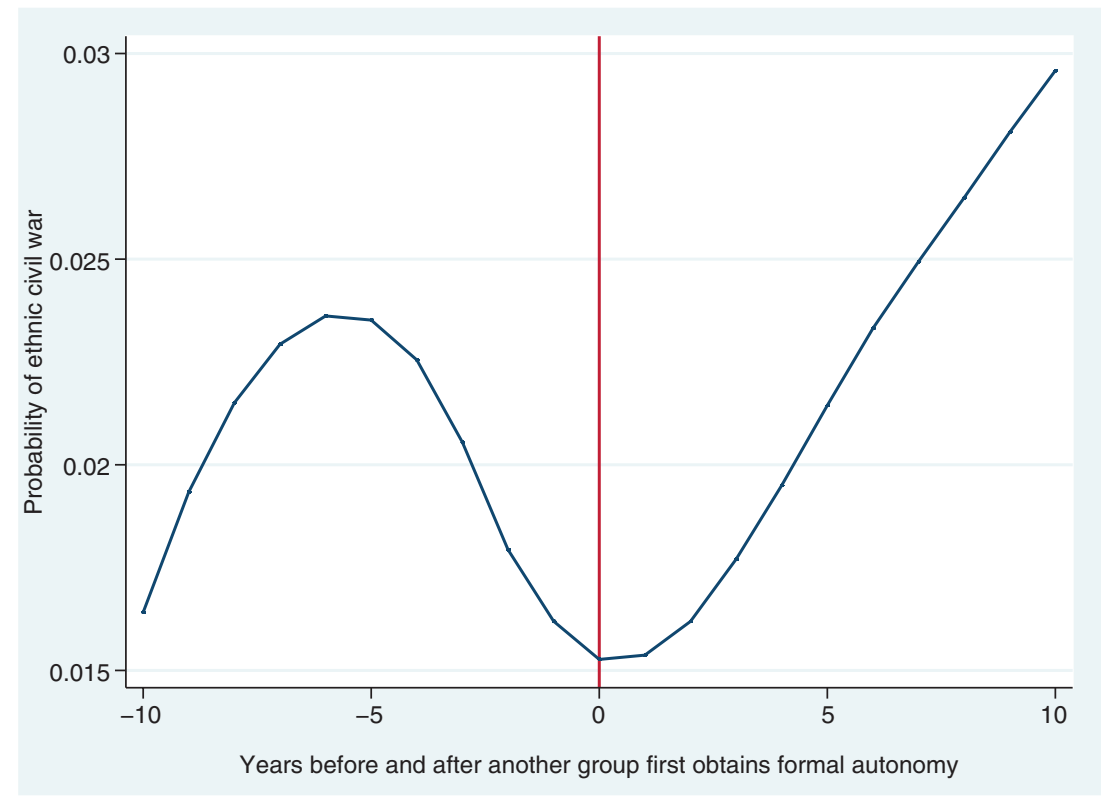

Figure 4: Risk of ethnic civil wars in the years leading up to and following formal regional autonomy first given to another group.

Source: Author' calculations based on EPR and RAI data. Formal autonomy stems from the RAI dataset. The risk of civil war is estimated by semiparametric groups fixed-effects regression.

autonomy) and then again at a similar pace following autonomy (it falls to $0 \% 10$ years after autonomy). This suggests that power-sharing detracts from conflict and that strategic behaviors are essentially absent.

Finally, does granting autonomy to one group encourage others to fight? Toft (2003) and Walter (2006) suggest that such contagion effect may exist, notably because granting autonomy can be interpreted as a sign of state weakness. ${ }^{12}$ Figure 4 suggests a non-linear relationship between the timing of autonomy to other groups and participation in civil wars. On the one hand, the risk of civil war strongly decreases during the 5 years preceding the granting of autonomy to another group and reaches a minimum of $1.5 \%$ at the time of autonomy. As soon as formal autonomy has been awarded, however, the risk of civil war starts to sharply go up. Over the 10 years that follow the granting of autonomy to another group, the risk of civil war doubles to reach $3 \%$. This seems to legitimize the

12 Forsberg (2013) does not find that territorial concessions (a different construct than autonomy) leads to any "domino effect" in an econometric analysis. 
concern that groups which witness other minorities successfully obtain autonomy would be encouraged, even after a delay, to themselves engage in secessionist violence.

\section{Conclusion}

Finding ways to prevent and mitigating ethnic civil wars is critical as about half of internal conflicts since WW2 were ethnic in nature (Wimmer, Cederman, and Min, 2009). Many scholars have advocated for regional autonomy to accommodate the presence of spatially concentrated minorities on the ground that it can preserve the integrity of the state while allowing enough degree of self-rule to prevent or abate conflict. Others have criticized this approach. Groups anticipate that regional autonomy will be granted to settle conflict, thus generating the incentive to engage in warfare. Autonomy may also strengthen and legitimize separatist tendencies or encourage other groups to fight. In this note, I have tried to shed light on the likely relationships between autonomy and ethnic conflict by looking at the timing of autonomy; some key correlates of autonomy and the dynamics of conflict and autonomy. Such an exercise helps giving some context and leads for interpretation to the results of large-N studies. I found that ethnic conflict (past or present) strongly increases the chance that autonomy is obtained; thus creating possible perverse incentives whereby groups that would otherwise remain peaceful take up arms. Looking at the joint dynamics of conflict and autonomy suggests that formal and actual regional autonomy are effective at curbing ethnic conflict from local majorities, without evidence that conflict peaks up in the lead up to autonomy. For local minorities, however, the likelihood of involvement in civil wars is high at the time formal autonomy is granted but is very low 10 years before or after this point, strongly suggesting that the prospect of obtaining formal autonomy is partly to blame for the ethnic violence. Finally, whereas there is evidence that during the process of granting autonomy to a given group, the risk of conflict from other groups in the country is diminishing; as soon as formal autonomy has been awarded, the risk of civil war from these other groups sharply increases over the next 10 years. Overall, this body of evidence is supportive of the idea of regional autonomy as an effective tool for conflict prevention and management although it may give rise to perverse dynamic strategic interactions between the state and ethnic minorities that needs to be further studied.

Acknowledgments: I would like to thank Petros Sekeris, Catherine Mueller and one anonymous referee for their advice and helpful comments. The usual disclaimer applies. 


\section{References}

Bachtinger, A., Steiner, J. (2004), Switzerland: Territorial Cleavage Management as Paragon and Paradox, in Amoretti, U., Bermeo, N., (eds.), Federalism and Territorial Cleavages, Johns Hopkins University Press, Baltimore and London.

Baltagi, B., Li, D., (2002), Series Estimation of Partially Linear Panel Data Models with Fixed Effects, Annals of Economics and Finance, vol. 3, pp. 103-116.

Bunce, V., (1999), Subversive Institutions: The Design and the Destruction of Socialism and the State, Cambridge University Press, Cambridge.

Cederman, L.-E., Hug, S., Schadel, A., Wucherpfennig, J., (2015), Territorial Autonomy in the Shadow of Conflict: Too Little, Too Late? American Political Science Review, vol. 109, pp. 354-370.

Christin, T., Hug, S., (2012), Federalism, the Geographic Location of Groups, and Conflict, Conflict Management and Peace Science, vol. 29, pp. 93-122.

Cornell, S.E., (2002), Autonomy as a Source of Conflict: Caucasian Conflicts in Theoretical Perspective, World Politics, vol. 54, pp. 245-276.

Fearon, J.D., Laitin, D.D., (1999), Weak States, Rough Terrain, and Large-Scale Ethnic Violence since 1945, Paper Prepared for Delivery at the 1999 Annual Meetings of the American Political Science Association (APSA), 2-5 September 1999, Atlanta, GA.

Forsberg, E., (2013), Do Ethnic Dominoes Fall? Evaluating Domino Effects of Granting Territorial Concessions to Separatist Groups, International Studies Quarterly, vol. 57, pp. 329-340.

Hale, H., (2004), Divided We Stand: Institutional Sources of Ethnofederal State Survival and Collapse, World Politics, vol. 56, pp. 165-193.

Hardgrave, R.L., (1993), India: The Dilemmas of Diversity, Journal of Democracy, vol. 4, pp. 54-68.

Hechter, M., (2000), Containing Nationalism, Oxford University Press, Oxford.

Hooghe, L., (2004), Belgium: Hollowing the Center, in Amoretti, U., Bermeo, N., (eds.), Federalism and Territorial Cleavages, Johns Hopkins University Press, Baltimore, MD.

Kymlicka, W., (1998), Is Federalism a Viable Alternative to Secession?” in Lehning, P., (ed.), Theories of Secessionism, Routledge Press, New York, pp. 111-150.

Lijphart, A., (1969), Consociational Democracy, World Politics, vol. 21, pp. 207-225.

Lijphart, A., (1996), The Puzzle of Indian Democracy: A Consociational Interpretation, American Political Science Review, vol. 90, pp. 258-268.

Lustick, I., Miodownik, D., Eidelson, R.J., (2004), Secessionism in Multicultural States: Does Sharing Power Prevent or Encourage it?, American Political Science Review, vol. 94, pp. 209-230.

Murshed, S.M., Tadjoeddin, M.Z., Chowdhury, A., (2009), Is Fiscal Decentralization Conflict Abating? Routine Violence and District Government in Java, Indonesia, Oxford Development Studies, vol. 37, pp. 397-421.

Nordquist, K.-A., (1998), Autonomy as a Conflict-Solving Mechanism: An Overview, in Markku Suksi (ed.), Autonomy: Applications and Implications, Kluwer, The Hague.

Panizza, U., (1999), On the Determinants of Fiscal Centralization: Theory and Evidence, Journal of Public Economics, vol. 74, pp. 97-139.

Riker, W., (1964), Federalism: Origin, Operation, Significance, Little, Brown and Company, Boston.

Roeder, P.G., (1991), Soviet Federalism and Ethnic Mobilization, World Politics, vol. 43, pp. 196-232. 
Suberu, R.T., (2001), Federalism and Ethnic Conflict in Nigeria, United States Institute of Peace Press, Washington, DC.

Toft, M.D., (2003), The Geography of Ethnic Violence: Identity, Interests, and the Indivisibility of Territory, Princeton University Press, Princeton and Oxford.

Tranchant, J.-P., (2008), Fiscal Decentralization, Institutional Quality and Ethnic Conflict: A Panel data Analysis, 1985-2001, Conflict, Security and Development, vol. 8, pp. 491-514.

Tranchant, J.-P., (2016), Decentralisation, Regional Autonomy and Ethnic Civil Wars: A Dynamic Panel Data Analysis, 1950-2010, IDS Working Paper, University of Sussex, Brighton, UK.

Vogt, M., Bormann, N.-C., Rüegger, S., Cederman, L.-E., Hunziker, P., Girardin, L., (2015), Integrating Data on Ethnicity, Geography, and Conflict: The Ethnic Power Relations Dataset Family, Journal of Conflict Resolution, vol. 59, pp. 1327-1342.

Walter, B.F., (2006), Information, Uncertainty, and the Decision to Secede, International Organization, vol. 60, pp. 105-135.

Weingast, B.R., (2014), Second Generation Fiscal Federalism: Political Aspects of Decentralization and Economic Development, vol. 53, pp. 14-25.

Wimmer, A., Cederman, L.-E., Min, B., (2009), Ethnic Politics and Armed Conflict: A Configurational Analysis of a New Global Data Set, American Sociological Review, vol. 74, pp. 316-337. 